Madrygal. Revista de Estudios Gallegos

ISSN: $1138-9664$

\title{
Poemas de Maria Cyranowicz
}

Rebeca Lema; Karolina Stępień

Maria Cyranowicz (Varsovia, 1974) é unha poeta e crítica literaria polaca, integrante da corrente literaria Neolingwizm (Neolingüismo), que propón o afastamento do texto poético clásico para reivindicar a importancia da poesía audiovisual. Estudou Filoloxía Polaca na Universidade de Varsovia, onde actualmente prepara a súa tese de doutoramento. Tamén traballa como editora da revista literaria Wakat, sobre a promoción das tendencias de vangarda na arte e literatura. Ten publicados diversos poemas e artigos en distintas revistas e xornais polacos coma Studium, Czas Kultury, Fa-Art, Twórczość, Ha!art ou Teksty Drugie. Ademais, é autora de cinco libros de poesía: neutralizacje (Fronda, Varsovia, 1997), i magii nacje (Zielona Sowa, Cracovia, 2001), piaty element to fiksja (Staromiejski Dom Kultury, Varsovia, 2004), psychodelicje (Staromiejski Dom Kultury, Varsovia, 2006) e denpresja (Fundacja Modern Art Means Modern Artist Language MAMMAL, Varsovia, 2009), e coeditora das antoloxías Gada !zabić? Pa(n)tologia neolingwizmu, xunto con Paweł Kozioł (Varsovia, 2005) e Solistki. Antologia poezji kobiet (19892009), xunto con Joanna Mueller e Justyna Radczyńska (Varsovia, 2009).

\section{Also das Kind das Kind war}

Kiedy dziecko było dzieckiem,

świat nie był całkiem niedobry.

Mleko smak miało metalu i dziecko

dmuchało zawzięcie do kubka.

Biały garb marszczył się pod kożuchem, a w oczach kwitly ciemne plamki.

Kiedy dziecko było dzieckiem, przeglądało się w tęczówkach łyżeczek i wszystko stawało na głowie.

Dziecko jadło chleb z masłem lub płatki [owsiane.

Codziennie dziecko układało

świat z kolorowych sześcianów, bardzo [niestabilny.

Wtedy każdy palec mógł się okazać [zawleczką,

\section{Also das Kind das Kind war}

Cando o neno era neno, o mundo non era malo de todo.

O leite a metal sabía e o neno sopráballe con cisma á cunca.

Unha gobia branca engurrábase baixo a tona e nos ollos florecían manchas escuras.

Cando o neno era neno, mirábase nos iris das culleriñas e todo quedaba patas arriba.

O neno comía pan con manteiga ou cereais [de avea.

Todos os días o neno encaixaba o mundo con cubos de cores, moi [inestable.

Daquela, calquera dedo podía converterse [nunha cavilla, 
każde mrugnięcie powieką Đ sygnałem

[apokalipsy,

kiedy dziecko było dzieckiem.

Dziś, kiedy dziecko jest dzieckiem, umie już kontrolować zdziwienie czarnych [brwi.

Udaje, że nie widzi, jak się z wrażenia otwierają okna. Nie dostrzega szaleństwa figlującego w prześwietlonych oczach. Patrzy, a na dole betonowe płyty. I czysto. Jak po [nikim.

\section{krótka kawa $\mathrm{z}$ niedługim papierosem (w stylu baro-ko-wym)}

W rytm wyrzucanych z kuchni: pierogi, [proszę! naleśniki!

zamawiam małą kawę ze śmietanką [(kontrolowany

przemarsz myśli trwa). Dobijając do burty

białego stołu jak blat prosektorium, wylewam,

bo przelewa mi się, odrobinę na spodek.

Rozglądam się uważnie, czy ktoś nie [zauważył

moich niezgrabnych podchodów, lecz [wszyscy śpią

wtopieni w swoje filiżanki. Wiosłuję więc [łyżeczką

przez brąz na samo dno, krótko mówiąc,

nie mówiąc do nikogo nic. Po chwili przerwa:

na kobietę nad miedzianą herbatą

(unika mego wzroku, choć nie może)

i papieros na przerwę, niedługi jak oddech. calquera chiscadela de ollo, nun sinal da [apocalipse,

cando o neno era neno.

Hoxe, cando o neno é neno,

xa sabe como manexar o asombro das cellas [negras.

Fai coma quen que non ve, como abraiadas ábrense as ventás. Non nota a tolemia brincadora nos ollos sobreexpostos. Mira e abaixo están as lousas de formigón. E [limpo. Coma despois de ninguén.

\section{un café curto cun breve cigarro (ao estilo bar-ro-co)}

Ao ritmo das lanzadas da cociña: empanadillas, [por favor! filloas!

pido un café pequeno con leite (o desfile

controlado de pensamentos segue). Arribando [ao babor

dunha mesa branca coma unha padiola de [disección, verto

-porque se me reverte- un chisco no prato.

Miro ao redor con coidado, se ninguén se [decatou

do meu torpe desatino, mais todos dormen

fusionados coas súas cuncas. Remo entón coa [culleriña

polo marrón cara ao mesmo fondo, en poucas [palabras,

sen lle dicir palabra a ninguén. Tras un intre, [un descanso:

para unha muller cun té cobreado

(evita a miña mirada, malia que non pode)

e un cigarro para o descanso, breve coma o [alento. 